較するのは問題があるといら御指適のように思われる が，著者らは両者の結果から，バルクと界面の酸素濃度 は一致すると考えた。一致する理由としては（i ）があげ られるが，このような場合には，傍証として引用して差 し支えないと考えられる.

また YAVOISKY らの結果からは, 酸素濃度が平衡を保 ちながら減少するとはいえないとの御指摘であるが, log $K_{\mathrm{Si}}$ の温度变化を HiLTy \& CRAFTs や GOKCEN \& GHIPMAN らのそれと比較した結果 (Fig. 5) をながめ, さ らに彼らがこれをもとに酸素活量の温度変化は equilibrium-reversible change であると述べていることをす な报に受け取つて, 平衡を保ちながら減少するとした.

(3) $\Delta \mathrm{O}$ と大粒子の酸素量との差は, a) $1555^{\circ} \mathrm{C}$ の溶解酸素濃度が平衡値に一致することから, 生成相の 組成としては $\mathrm{SiO}_{2}$ が妥当と考えられること，およびb) 冷却過程では大粒子以外に観察可能な大ささの $\mathrm{SiO}_{2}$ 粒 子は生成しないことから, きわめて微細な $\mathrm{SiO}_{2}$ である と考えた.

界面張力に関する仮定は，前記の（i )の事柄を説明す るのに，どうしても従来の核生成一成長理論からはみで る必要があると考竞たからであるが，もちろん直接的な
証拠があるわけではないので，この仮定も含めて著者ら の考方方が妥当かどらかは今後の批判を待ちたいと思 う.ただ界面張力の熱力学的取り扱いを $100 \AA$ 以下ま で拡張するのは無意味と述べておられるように，従来の 核生成論を適用できない実例が，脱酸のような身近な製 鋼反応のなかにも現存しているのではないかといらこと と, そのような場合の解釈の一つを提起したものと御理 解いただきたい.

また Si-O クラスターを考えてはどらかといら点につ いては, 微細 $\mathrm{SiO}_{2}$ は大きさがせいぜい数十 $\AA$, 形は球 形ではなさそうだといらことを推定しただけで，その実 態は明確ではない. しかしながらクラスターを考えても 事情はまつたく同様のように思われ，現状では明快にお 答えしかねる。

なお微細 $\mathrm{SiO}_{2}$ の容易な生成とこれを構成単位とした $\mathrm{SiO}_{2}$ 粒子の成長は, 冷却凝固時に特有な機構ではなく, $\mathrm{Si}$ 添加後の脱酸過程についても当てはまると考兄られ る. この場合, 脱酸速度は $\mu$ 程度に成長した粒子の浮上 分離ではなく, 生成した微細生成物の主として器壁への 付着速度によつて律速されると考えられることを付言し たい.

\begin{tabular}{|c|c|}
\hline 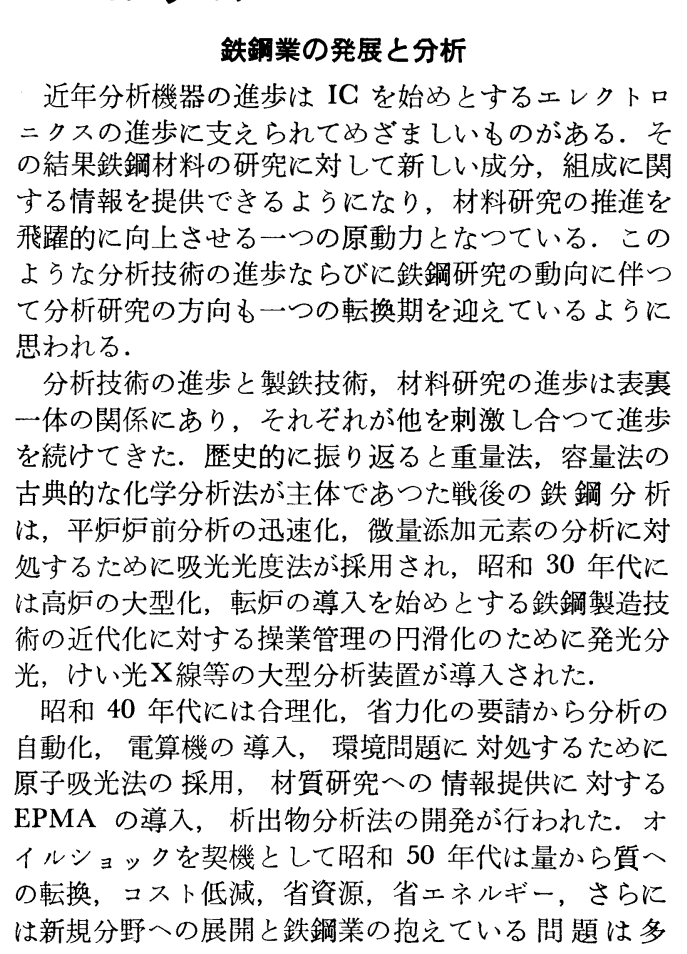 & 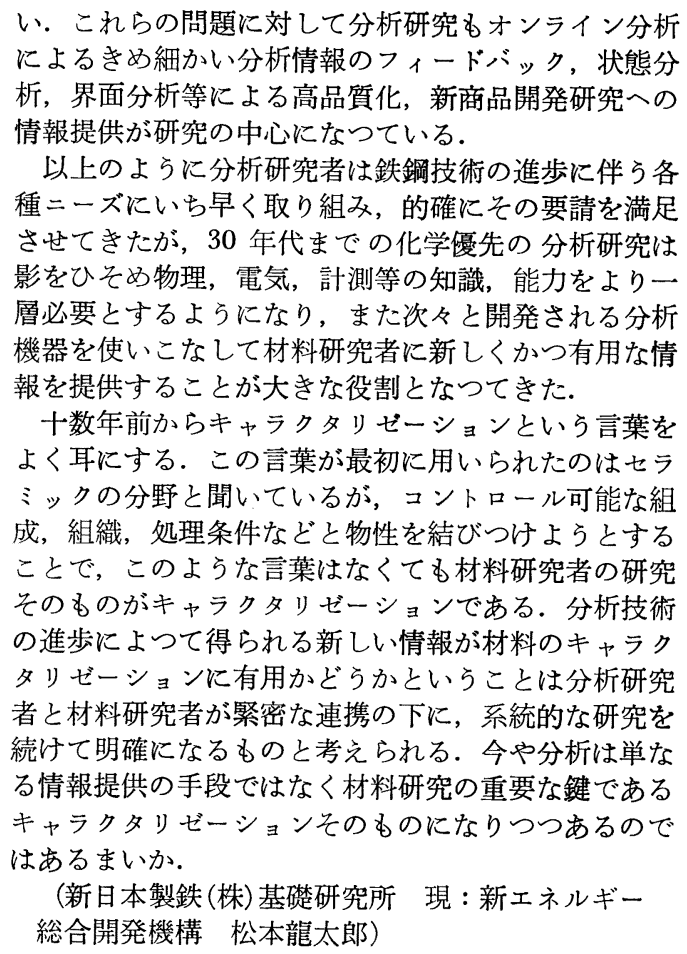 \\
\hline
\end{tabular}




\section{鉄鋼材料 革命}

低成長時代を迎えるなかで，鋼の製品革命が進んで いる. いわゆる“高級鋼ブーム”である．歷史的にみ て鋼は高級化(高強度化)する傾向にあつた。しかし， 昭和 48 年の第一次石油危機以降, この動きに拍車が かかつた。これの最大原因は石油危機に端を発したエ ネルギー制約への対応であり，供給，利用両面での社 会構造, 産業構造の変化がもたらした材料に対する二 一ズの転換とみることができる。この新しいニーズを 受けて，極塞地向けあるいは耐サワー用油井管やライ ンパイプ用鋼板，自動車の軽量化のための高強度薄板， 耐久性向上のための防錆鋼板, LNG, LPG タンク用 低温用高性能鋼, 電気機器の電力損失をできるだけ少 なくすることを目的とした高性能電気鋼板等多種の新 しい鋼材が開発され，そして需要が急増している。 こ の高級化はすべての品種において表れており，また，

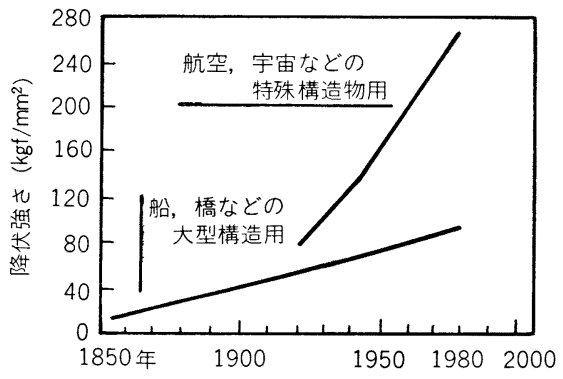

(出所：内山郁編，鉄鋼・高強度に挑む)

構造用鉄鋼材料の強さレベルの変遷
同種の動きが鉄鋼以外の材料分野においてるみられる ことから，ひとつの大きな材料革命とみることができ よう.

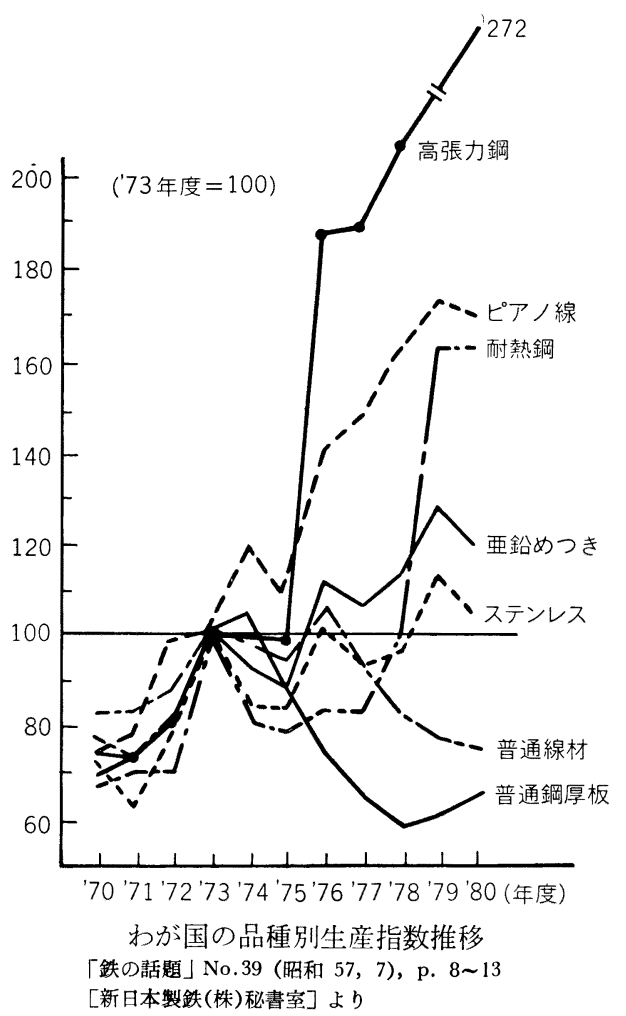

編集後記

研究者, 技術者にとつて, 「創造性」は重要であり, 「鉄と鋼」は日本鉄鋼業の基盤となつている技術につ いての「創造性発揮」の集約版として長い歴史の中で 重要な役割を果たしてきた。

かつて，ノーベル賞学者の湯川博士が独創性（厳密 には独創性と創造性とは意味が異なるが）について語 つていた文章を読んだことがあるが，その中で博士は 「研究者は古くなればなるほど, 既成概念のカタマリ になつて行く.したがつて，そのことを自覚し，また， それを日々打ち破る努力が独創性を生む基である.」 といら主旨のことを述べていた。

なるほど，そのと扣りで, 研究者，技術者も年々「既 成概念」を蓄積して抢り，その中で発想を転換するこ とは「既成概念」が邪魔になつてなかなかむつかしく なつてくる.
昨今の鉄鋼業では, 新しい分野の研究開発の比重が 拡大して打り, 従来, 鉄鋼プロパーの研究, あるいは 技術に携つてきた人達が，新しい分野に否応なく振り 向けられて行き，一方で，これまで高いレベルに維持 してきた技術ポテンシャルを限られた人材で保持し， かつ向上することが求められる厳しい状況に直面して きている. その意味で, 鉄鋼関連の研究者, 技術者は 「既成概念のカタマリ」を自覚し, 新しい発想を生み だすことが必要であり，「鉄と鋼」の編集を委託され たものとしては新しい発想の論文, 報告を十分感度 よくキャッチし，伸ばすことが必須であると痛感され る.

今月は, 鉄鋼関連の先端材料, 先端技術の解説, 展 望, 委員会報告記事がわかりやすく説明されている. 参考にしていただければ幸いである。 